\title{
Physicochemical and nutritional properties of jussara pulp powder (Euterpe edulis
}

\author{
M.) by spray-drying \\ Propriedades físico-químicas e nutricionais da polpa da juçara (Euterpe edulis M.) em pó \\ desidratada por atomização \\ Propiedades fisicoquímicas y nutricionales de la pulpa de jussara en polvo (Euterpe edulis M.) por \\ secado por atomización
}

Received: 12/16/2020 | Reviewed: 12/24/2020 | Accept: 01/19/2021 | Published: 01/24/2021

\author{
Linda Mariana Oliveira Da Silva \\ ORCID: https://orcid.org/0000-0002-8303-0541 \\ Federal University of Maranhão, Brazil \\ E-mail: lindamarianaa@gmail.com \\ Gustavo Augusto Silva Santos \\ ORCID: https://orcid.org/0000-0002-9877-7779 \\ Federal University of Maranhão, Brazil \\ E-mail: gustavoaugusto_silvasantos@hotmail.com \\ Adones Almeida Rocha \\ ORCID: https://orcid.org/0000-0001-7282-3290 \\ Federal University of Maranhão, Brazil \\ E-mail: adonesalmeida02@gmail.com \\ Ana Karoliny Da Silva Raposo \\ ORCID: https://orcid.org/0000-0001-9057-8022 \\ Federal University of Maranhão, Brazil \\ E-mail: anakarolinyraposo@gmail.com \\ Louryval Coelho Paixão \\ ORCID: https://orcid.org/0000-0001-7241-1800 \\ Federal University of Maranhão, Brazil \\ E-mail: louryvalp@gmail.com \\ Audirene Amorim Santana \\ ORCID: https://orcid.org/0000-0003-3149-6822 \\ Federal University of Maranhão, Brazil \\ E-mail: audirene.amorim@gmail.com
}

\begin{abstract}
The jussara palm (Euterpe edulis) is well known for its great presence in several Brazilian states and produces an edible palm heart and spherical fruits popularly known as jussara. Due to their high anthocyanin content, these fruits contain only one light brown seed that is covered by thin and dark purple skin. This study was carried out to evaluate the effects of different mixtures of carrier agents (CA) (modified starch-MS plus whey protein concentrate-WPC or soy protein isolate-SPI) on the characteristics of microcapsules containing spray-dried jussara pulp powder. Four treatments, $30 \% \mathrm{CAC}+17.5 \% \mathrm{MS}: \mathrm{WPC}, \quad 17.5 \% \mathrm{CAC}+30 \% \mathrm{MS}: \mathrm{WPC}, \quad 30 \% \mathrm{CAC}+17.5 \% \mathrm{MS}: \mathrm{SPI}$ and 17.5\% CAC+30\%MS:SPI, were evaluated, where $\mathrm{CAC}=$ carrier agent concentration (g carrier/g jussara pulp solids) and the proportions MS:WPC and MS:SPI indicate the grams of protein (WPC or SPI) per 100g of carrier. The concentration of $30 \% \mathrm{CAC}+17.5 \% \mathrm{MS}: \mathrm{WPC}$ improved the wettability, anthocyanin content, total phenolic content and encapsulation efficiency. The particles presented smoother surfaces with a reduced number of folds when WPC was present. The usage of WPC or SPI mutually with MS was shown as a valid option in the spray drying of jussara pulp.

Keywords: Euterpe edulis Martius; Whey protein concentrate; Modified starch; Soy protein isolate.
\end{abstract}

\section{Resumo}

A palmeira jussara (Euterpe edulis) é bastante conhecida por sua grande presença em vários estados brasileiros e produz um palmito comestível e frutos esféricos conhecidos popularmente como jussara. Devido ao seu alto teor de antocianinas, esses frutos contêm apenas uma semente marrom-clara que é coberta por uma casca fina e roxa escura. Este estudo foi realizado para avaliar os efeitos de diferentes misturas de agentes carreadores (CA) (amido modificado mais concentrado de proteína de soro de leite-WPC ou isolado de proteína de soja-SPI) sobre as características de microcápsulas contendo polpa de jussara em pó. Quatro tratamentos, 30\% CAC + 17,5\% MS: WPC, 17,5\% CAC + $30 \%$ MS: WPC, $30 \%$ CAC + 17,5\% MS: SPI e 17,5\% CAC + 30\% MS: SPI, foram avaliados, onde CAC = portador a concentração do agente (g carreador / g sólidos da polpa de jussara) e as proporções MS: WPC e MS: SPI indicam os 
gramas de proteína (WPC ou SPI) por $100 \mathrm{~g}$ de carreador. A concentração de $30 \%$ CAC + 17,5\% MS: WPC melhorou a molhabilidade, o conteúdo de antocianina, o conteúdo fenólico total e a eficiência de encapsulação. As partículas apresentaram superfícies mais lisas com número reduzido de dobras quando o WPC estava presente. O uso de WPC ou SPI mutuamente com MS mostrou-se uma opção válida na secagem por atomização da polpa de jussara.

Palavras-chave: Euterpe edulis Martius; Concentrado protéico do soro; Amido modificado; Isolado protéico de soja.

\section{Resumen}

La palma jussara (Euterpe edulis) es bien conocida por su gran presencia en varios estados brasileños y produce un palmito comestible y frutos esféricos conocidos popularmente como jussara. Debido a su alto contenido de antocianinas, estas frutas contienen solo una semilla de color marrón claro que está cubierta por una piel fina y de color púrpura oscuro. Este estudio se llevó a cabo para evaluar los efectos de diferentes mezclas de agentes portadores (CA) (almidón modificado-MS más concentrado de proteína de suero-WPC o aislado de proteína de soja-SPI) sobre las características de las microcápsulas que contienen polvo de pulpa de jussara secada por aspersión. Se evaluaron cuatro tratamientos, $30 \% \mathrm{CAC}+17.5 \% \mathrm{MS}$ : WPC, $17.5 \% \mathrm{CAC}+30 \% \mathrm{MS}: \mathrm{WPC}, 30 \% \mathrm{CAC}+17.5 \% \mathrm{MS}: \mathrm{SPI}$ y $17.5 \% \mathrm{CAC}+30 \% \mathrm{MS}: \mathrm{SPI}$, donde $\mathrm{CAC}=$ portador la concentración del agente $(\mathrm{g}$ de portador $/ \mathrm{g}$ de sólidos de pulpa de jussara) y las proporciones MS: WPC y MS: SPI indican los gramos de proteína (WPC o SPI) por $100 \mathrm{~g}$ de portador. La concentración de 30\% CAC + 17,5\% MS: WPC mejoró la humectabilidad, el contenido de antocianinas, el contenido fenólico total y la eficiencia de encapsulación. Las partículas presentaron superficies más suaves con un número reducido de pliegues cuando estaba presente WPC. El uso de WPC o SPI junto con MS se mostró como una opción válida en el secado por aspersión de pulpa de jussara.

Palabras clave: Euterpe edulis Martius; Concentrado de proteína de suero; Almidón modificado; Aislado de proteína de soja.

\section{Introduction}

Currently, there is a great deal of interest in the health-giving properties of fruits and vegetables, since their intake appears to be associated with a reduced risk of chronic and degenerative diseases (Shishir \& Chen, 2017). This protective effect seems to be linked to their antioxidant activity, mainly related to the presence of vitamins $\mathrm{C}$ and $\mathrm{E}$, carotenoids, anthocyanins, betalains and polyphenols (Ferrari et al., 2012; Hinneburg et al., 2016; Shishir \& Chen, 2017; García-Lucas et al., 2017).

The jussara palm (Euterpe edulis) is extensively diffused throughout the Brazilian Atlantic Forest and offers edible palm hearts and spherical fruits identified as jussara. Because of their high anthocyanin content, these fruits include a single one light brown seed that is covered by thin and dark purple skin. (Borges et al., 2011).

The anthocyanin compounds are frequently sensitive to perishable effects while is being processed and stored, due to their sensibility to unfavorable environmental circumstances, like high warmth, light, and oxygen. For this reason, the spray drying process fits as an option to enhance the conservation of the final product. Also, to prevent some problems, the addition of carrier agents to the feed solution before atomization is recommended, thus producing free-flowing powders, avoiding stickiness, reducing powder hygroscopicity, and enhancing process yield (Maia et al. 2019). Moreover, the carrier agents can also protect sensitive food components against unfavorable environmental conditions (Nambi et al., 2017).

The objective of this research was to estimate the influence of different mixes of carrier agents on the physicochemical and nutritional properties of spray-dried jussara powder investigating wettability, anthocyanin content, total phenolic content, encapsulation efficiency, particle size and morphology.

\section{Materials and Methods}

\subsection{Materials}

Jussara fruit was provided by local farmers of Ubatuba, São Paulo, Brazil. During pulping, water was added, (pulp:water ratio 1:2, w/w) and the jussara pulp was then packed into plastic bottles $(1 \mathrm{~L})$ and immediately frozen, due to its high perishability.

The main characteristics of the jussara pulp, determined according to AOAC (AOAC, 2006), were (on a wet basis): 
moisture content of $79.59 \pm 0.08 \mathrm{~g} / 100 \mathrm{~g}$, protein content of $4.49 \pm 0.05 \mathrm{~g} / 100 \mathrm{~g}$, fat content of $19.59 \pm 0.12 \mathrm{~g} / 100 \mathrm{~g}$, ash content of $1.03 \pm 0.01 \mathrm{~g} / 100 \mathrm{~g}$, total sugar content of $4.62 \pm 1.46 \mathrm{~g} / 100 \mathrm{~g}$, reducing sugar content of $3.20 \pm 0.56 \mathrm{~g} / 100 \mathrm{~g}$, titratable acidity of $0.23 \pm 0.02 \mathrm{~g}$ citric acid $/ 100 \mathrm{~g}, \mathrm{pH}$ of $4.99 \pm 0.07$, total soluble solids of $10.15 \pm 0.21^{\circ} \mathrm{Brix}$ and vitamin $\mathrm{C}$ content of $30.59 \pm$ $0.98 \mathrm{mg} / 100 \mathrm{~g}$ (Santana et al., 2016). The anthocyanin content were determined according to Cinquanta et al. (2002) and was $8.35 \pm 0.36 \mathrm{mg} / \mathrm{g}$.

The carrier agents used were: modified starch (Hi-Cap 100, National Starch, São Paulo, Brazil), whey protein concentrate (WPC 80, Alibra, Campinas, Brazil) and soy protein isolate (SPI SUPRO® 783, Solae, Barueri, Brazil).

\subsection{Mixture Viscosity}

The viscosity of the feed mixtures was determined from the steady-shear flow curves (shear stress $\times$ shear rate) using a controlled stress R-2000EX rheometer (TA Instruments, Delaware, USA) at $25^{\circ} \mathrm{C}$ with a geometry of serrated parallel plates (Ø40 mm) and a gap of $500 \mu \mathrm{m}$. These conditions were adopted based on preliminary results (Santana et al., 2016). Samples of $2.0 \mathrm{~mL}$ were introduced into the rheometer with the aid of an automatic pipette. All tests were carried out in duplicate and a new sample was used for each replicate. The solvent trap rheometer accessory was used during measurements in order to prevent solvent evaporation. Flow curves were obtained from three shear rate ramps carried out in the following order: increasing-decreasing-increasing shear rate in the range from 0.1 to $250 \mathrm{~s}-1$.

The rheograms were analysed according to empirical models of the flow curves corresponding to the second (decreasing) shear rate ramp, and the apparent viscosity was calculated as the ratio of shear stress $(\sigma)$ to shear rate $(\gamma)$.

\subsection{Sample Preparation}

With the use of a Büchner funnel, the jussara pulp was vacuum filtered; this procedure was completed before the spray drying process, removing suspended solids that could muddle the process. Different concentrations of binary combinations of the encapsulating matrices containing the jussara extract were subjected to the process. The mixture was dissolved in an 'Ultra-Turrax' (IKA T25 D, Staufen, Germany) homogenizer at room temperature and 14,000 rpm for 10 minutes, with the goal of complete dissolution, and maintained under magnetic agitation during the passage of the solutions through the atomizer nozzle.

\subsection{Microcapsule production and analysis}

The solutions prepared in the item before were fed into the BÜCHI Mini Spray B-290 (Flawil, Switzerland) spray dryer equipped with a two-fluid nozzle atomizer (diameter $7 \mathrm{~mm}$ ). These solutions were put into the chamber at an inlet drying air temperature of $170^{\circ} \mathrm{C}$ corresponding to an outlet air temperature of $100-110^{\circ} \mathrm{C}$. The flow rate of the peristaltic pump was 5 $\mathrm{ml} / \mathrm{min}$, aspirator rate of $90 \%$, spraying air flow rate of $500 \mathrm{~L} / \mathrm{h}$, carrier agent concentrations of 1.25 and 2.0 (17.5 and $30 \%) \mathrm{g}$ carrier/g jussara pulp solids and proportions of 17.5 and 30 (17.5 and 30\%) g protein/100 g carrier. The spray dryer powders were stored in sealed plastic bags and placed in desiccators for further analysis.

\subsubsection{Visual aspect}

A subjective analysis was carried out in order to evaluate the visual aspects of the powder, analyzing the visual parameters of homogeneity and thickness.

\subsubsection{Wettability}

The wettability of the powders was determined according to Edris et al. (2016). About $1 \mathrm{~g}$ of powder was sprinkled 
over the surface of $400 \mathrm{~mL}$ of distilled water at $25^{\circ} \mathrm{C}$ without agitation. The time taken for the last powder particle to submerge was recorded and used in a relative comparison of the extent of wettability between the samples. The results were expressed as the mean of eight repetitions.

\subsubsection{Anthocyanin content}

The total anthocyanin content (TA) was determined by the spectrophotometric method of Francis (Francis, 1982). About $10 \mathrm{mg}$ of powder were extracted twice with $10 \mathrm{ml}$ of a $\mathrm{HCl} /$ water/ethanol solution (1/29/70). The extract was centrifuged for $10 \mathrm{~min}$ at 10,000 $\times \mathrm{g}$ and the absorbance recorded in a Beckman DU-7-B340 (Beckman, Krefeld, Germany).

The total anthocyanin content was expressed as cyanidin-3-rutinoside, which was previously identified as the major anthocyanin present in jussara (Brito, et al., 2007). The molar absortivity (Emolar) of cyanidin-3-rutinoside used was 32,800 at $\lambda \max$ absorbance (about $534 \mathrm{~nm}$ ), in $\mathrm{HCl} /$ water/ethanol solution (1/29/70) at $20^{\circ} \mathrm{C}$ (Cinquanta, Dimatteo, \& Esti, 2002). The analysis was repeated in triplicate.

The retention of total anthocyanins (RTA), obtained after spray drying, was calculated according to Eq. 1:

$R T A(\%)=\frac{T A_{\text {powder }}}{T A_{\text {pulp }}} \times 100$

\subsubsection{Encapsulation efficiency}

To estimate the effectiveness of microencapsulation, the TA content and surface anthocyanins of the microcapsules were determined from the ratio of TA to the surface anthocyanins. For the measurement of TA, the extracts were prepared as described in the item of anthocyanin content.

For the determination of surface anthocyanins (SA), $100 \mathrm{mg}$ of samples were extracted with $10 \mathrm{~mL}$ ethanol in a vortex for $30 \mathrm{~s}$, succeeded by centrifugation at 3,000Îg rpm for $10 \mathrm{~min}$ at $20^{\circ} \mathrm{C}$. After phase separation, the clear supernatant was collected and filtered through a 0.45 -mm-pore sized Millipore membrane.

The anthocyanin contents corresponding to the values for TA and SA were determined according to Cinquanta et al. (2002). The encapsulation efficiencies were determined based on the modified equation of Barbosa et al. (2005) as noted in Eq. 2.

$E E(\%)=\frac{(T A-S A)}{T A} \times 100$

The results were expressed as the mean of triplicates.

\subsubsection{Total phenolic compounds}

The phenolic compounds were determined by the Folin-Ciocalteau method as described by George et al. (2007). Briefly, in a series of glass tubes, $0.1 \mathrm{~g}$ of each sample was mixed with $20 \mathrm{~mL}$ distilled water and $2.5 \mathrm{~mL}$ of Folin-Ciocalteau reagent. After $2 \mathrm{~min}, 2 \mathrm{ml}$ of sodium carbonate solution $(75 \mathrm{~g} / \mathrm{l})$ were added to each test tube, mixed and allowed to stand in the dark at a temperature of $50{ }^{\circ} \mathrm{C}$ for $15 \mathrm{~min}$. The absorption of the samples was then measured at $760 \mathrm{~nm}$ using a Unico SQ2800 UV-Vis spectrophotometer. Distilled water was used as the blank sample. The total phenolic compound content was expressed as mg of gallic acid equivalents (GAE)/g of dry pulp. Each sample was evaluated in triplicate. 


\subsubsection{Morphology of the powder particles}

The microstructures of the particles were evaluated by scanning electron microscopy (SEM). The powders were attached to SEM stubs using double-sided adhesive tape, and coated with gold/palladium under vacuum in a sputter coater (model SC7620, VG Microtech, Ringmer, UK) at a coating rate of $0.51 \mathrm{~A} \% \mathrm{~s}, 3-5 \mathrm{~mA}, 1 \mathrm{~V}$, at $0.08-0.09 \mathrm{mbar}$ for $180 \mathrm{~s}$. The coated samples were examined using a Leica scanning electron microscope (model LEO440i) (Leica Electron Microscopy Ltd., Oxford, England). The SEM was carried out at $10 \mathrm{kV}$ and $50 \mathrm{pA}$ with magnifications of 1,000×.

\subsubsection{Particle size distribution}

The particle size distribution was measured using a Mastersizer S laser light scattering analyzer (Malvern Instruments, Malvern, U.K.). A small amount of powder was dispersed in 99\% isopropanol, and the particle size distribution monitored during five successive readings. Particle size was expressed as the mean volumetric size D[4,3] (De Brouckere mean diameter), which represents the mean diameter of a sphere with the same volume and is generally used to characterize a particle.

\section{Results and Discussion}

\subsection{Visual Aspect}

The visual aspect of the jussara pulp powder was evaluated; the powders had apparent low granulometry, confirmed by particle size analysis, and homogeneous color, ranging on the formulations from brownish to purple, shown in Figure 1.

Figure 1 - Photographs of spray-dried jussara pulp powder: (a) and (b) correspond to the tests 30\%CAC+17.5\%MS:WPC and 17.5\% CAC+30\%MS:WPC, respectively, and (c) and (d) correspond to the tests 30\%CAC+17.5\%MS:SPI and $17.5 \% \mathrm{CAC}+30 \% \mathrm{MS}: \mathrm{SPI}$, respectively.

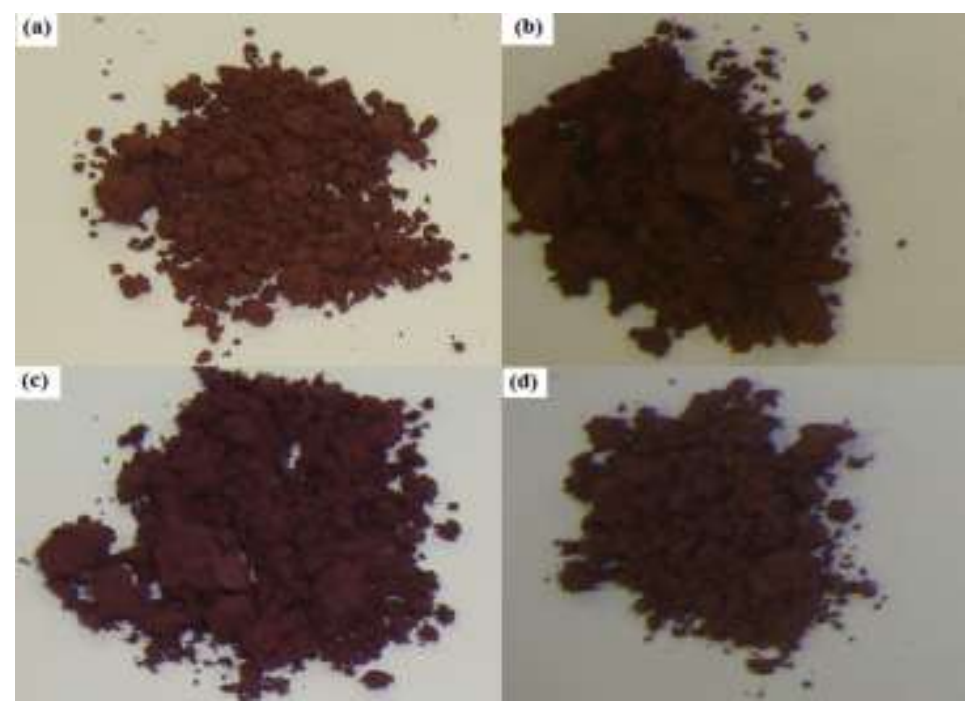

Source: Authors (2020).

\subsection{Viscosity of the mixture}

As stated before, the viscosity of the feed mixtures was determined from the steady-shear flow curves. The most appropriate mathematical model for describing the flow characteristics was the Power Law, with flow behaviour indexes (n) below 1 for all four treatments, 30\%CAC+17.5\%MS:WPC, 17.5\%CAC+30\%MS:WPC, 30\%CAC+17.5\% MS:SPI and 
17.5\%CAC+30\%MS:SPI. Thus the mixture "filtered jussara pulp + MS:WPC or MS:SPI" could be characterized as a fluid with shear-thinning behaviour, which is typical of most food materials, especially fruit pulps (Tonon et al., 2008).

The apparent viscosity was calculated as the ratio between shear stress and shear rate. The apparent viscosity of the samples increased with increasing concentration of MS:WPC or MS:SPI (Table 1).

Table 1 - Apparent viscosity, wettability and particle size of jussara pulp powders produced with a mixture of different carrier agents.

\begin{tabular}{cccc}
\hline Type & Apparent viscosity (Pa.s) & Wettability (s) & Particle size $-D[4,3](\mu \mathrm{m})$ \\
\hline $30 \%$ CAC+17.5\%MS:WPC & $0.026^{\mathrm{b}}$ & $198 \pm 0.38^{\mathrm{d}}$ & $10.93 \pm 0.77^{\mathrm{a}}$ \\
& $0.076^{\mathrm{d}}$ & $154 \pm 0.12^{\mathrm{c}}$ & $14.20 \pm 1.71^{\mathrm{b}}$ \\
$17.5 \% \mathrm{CAC}+30 \% \mathrm{MS}: \mathrm{WPC}$ & $0.019^{\mathrm{a}}$ & $133 \pm 0.16^{\mathrm{b}}$ & $12.18 \pm 1.49^{\mathrm{a}}$ \\
$30 \% \mathrm{CAC}+17.5 \% \mathrm{MS}:$ SPI & $0.064^{\mathrm{c}}$ & $98 \pm 0.07^{\mathrm{a}}$ & $15.41 \pm 1.75^{\mathrm{b}}$ \\
$17.5 \% \mathrm{CAC}+30 \% \mathrm{MS}:$ SPI & & & \\
\hline
\end{tabular}

$\mathrm{CAC}=$ carrier agent concentration; $\mathrm{MS}=$ modified starch; $\mathrm{WPC}=$ whey protein concentrate; $\mathrm{SPI}=$ soy protein isolate. Apparent viscosity on shear rate of $100 \mathrm{~s}^{-1}$

a,b,c,d $=$ Means in the same column followed by the same superscripts are not significantly different at $\mathrm{p}<0.05$ by Tukey's test Source: Authors (2020).

\subsection{Particle size and wettability}

The mean diameter of the particles $\mathrm{D}[4,3]$ (Brouckere mean diameter) gives an indication of the diameter corresponding to the average particle volume in the particle size distribution, and the span value. The mean diameters of the particles were $10.93 \mu \mathrm{m}, 14.20 \mu \mathrm{m}, 12.18 \mu \mathrm{m}$ and $15.41 \mu \mathrm{m}$ for the $30 \% \mathrm{CAC}+17.5 \% \mathrm{MS}: \mathrm{WPC}, 17.5 \% \mathrm{CAC}+30 \% \mathrm{MS}: \mathrm{WPC}$, $30 \% \mathrm{CAC}+17.5 \% \mathrm{MS}: \mathrm{SPI}$ and $17.5 \% \mathrm{CAC}+30 \% \mathrm{MS}: \mathrm{SPI}$ treatments, respectively (Table 1).

The particle size was significantly affected $(\mathrm{p}<0.05)$ by the amount of protein in the wall material, with the highest values observed when $17.5 \% \mathrm{CAC}+30 \% \mathrm{MS}$ :WPC and $17.5 \% \mathrm{CAC}+30 \% \mathrm{MS}$ :SPI were used as the treatments. Low amounts of protein in the wall materials decreased the mean particle size. The larger particle sizes produced using the 17.5\% CAC+30\%MS:WPC and 17.5\% CAC+30\%MS:SPI treatments could be explained by the higher emulsion viscosities of these formulations when compared with the other treatments. According to Jafari et al. (2017), the greater the feed viscosity, the larger the droplets formed during atomization and consequently, the larger the particle size. Control of the particle size during the spray drying process is important due to its great effect on the appearance, flowability and dispersibility of the particles (Reneccius, 2004).

Wettability can be defined as the ability of a powder bulk to be penetrated by a liquid due to capillary forces (de Beer et al., 2018). This instant powder property is inversely related to the particle size, because larger particles show more spaces between them, being more easily penetrated by water. On the other hand, smaller particles are less porous, making it more difficult for the liquid to penetrate into the food matrix, which results in poor reconstitution properties. The particles exhibited a wettability time ranging from 98 s to 198 s. Similar values were obtained by Brotel et al. (2014) and Ferrari et al. (2012) working with fish oil and blackberry, respectively. The MS:WPC samples presented a greater formation of lumps than the MS:SPI samples, increasing the wettability time. The presence of SPI decreased the wettability time as compared to that of the treatment using WPC, most likely by increasing the content of hydrophilic groups in the particles, which interact well with 
water. Moreover, the greater amount of surface oil on the powders produced using MS:WPC contributed to an increase in hydrophobicity, hindering the spread of water over the surface of these particles.

\subsection{Anthocyanin content, total phenolic content and encapsulation efficiency}

The microcapsules generated were analyzed according to the methods explained previously and the results reported in Table 2.

Table 2 - Anthocyanin content, total phenolic content and encapsulation efficiency of jussara pulp powders produced with a mixture of different carrier agents.

\begin{tabular}{|c|c|c|c|}
\hline Type & $\begin{array}{l}\text { Anthocyanin content } \\
\qquad(\mathrm{mg} / \mathrm{g})\end{array}$ & $\begin{array}{l}\text { Total phenolic content (mg } \\
\text { GAE/g) }\end{array}$ & $\begin{array}{c}\text { Encapsulation efficiency } \\
(\%)\end{array}$ \\
\hline $30 \% \mathrm{CAC}+17.5 \% \mathrm{MS}: \mathrm{WPC}$ & $7.61 \pm 0.11^{\mathrm{a}}$ & $90.33 \pm 3.71^{\mathrm{a}}$ & $99.74 \pm 0.02^{\mathrm{a}}$ \\
\hline $17.5 \% \mathrm{CAC}+30 \% \mathrm{MS}: \mathrm{WPC}$ & $6.88 \pm 0.43^{\mathrm{b}}$ & $61.64 \pm 5.55^{\mathrm{b}}$ & $99.43 \pm 0.11^{\mathrm{b}}$ \\
\hline $30 \% \mathrm{CAC}+17.5 \% \mathrm{MS}: \mathrm{SPI}$ & $6.91 \pm 0.06^{\mathrm{b}}$ & $69.87 \pm 4.81^{b}$ & $99.46 \pm 0.04^{\mathrm{b}}$ \\
\hline $17.5 \% \mathrm{CAC}+30 \% \mathrm{MS}: \mathrm{SPI}$ & $5.43 \pm 0.15^{\mathrm{c}}$ & $50.69 \pm 3.38^{c}$ & $99.26 \pm 0.11^{\mathrm{c}}$ \\
\hline
\end{tabular}

$\mathrm{CAC}=$ carrier agent concentration; $\mathrm{MS}=$ modified starch; $\mathrm{WPC}=$ whey protein concentrate; $\mathrm{SPI}=$ soy protein isolate

$\mathrm{a}, \mathrm{b}, \mathrm{c}=$ Means in the same column followed by the same superscripts are not significantly different at $\mathrm{p}<0.05$ by Tukey's test Source: Authors (2020).

Anthocyanins provide the characteristic color of fruits and vegetables. Unstable anthocyanins are negatively affected by heating and finally denatured or polymerized with other phenolic compounds causing a loss of color (Ahmed et al., 2010; Jafari et al., 2017).

As shown in Table 2, with the higher carrier agent concentration (30\%) (g carrier/g solids jussara pulp) and lower proportion of protein $(17.5 \%)(\mathrm{g}$ protein/100 g carrier) there was a sharp increase in anthocyanin content. At this value of CAC, the encapsulation of anthocyanins was sufficient. Ferrari et al. (2012) and Paim et al. (2016) found similar values for blackberry powder (varied between 6.28 and $6.42 \mathrm{mg} / \mathrm{g}$ dried juice) and jussara juice powder (varied between 5.75 and 7.39 $\mathrm{mg} / \mathrm{g}$ dried juice). The values obtained in this study were higher than those obtained for purple sweet potato flour (from 5.20 to $5.70 \mathrm{mg} / \mathrm{g}$ dry matter) and bayberry powder (around $5.70 \mathrm{mg} / \mathrm{g}$ dry matter), both produced by spray drying (Ahmed et al., 2010; Fang \& Bhandari, 2011).

The total phenolic contents of the particles were $90.33 \mathrm{mg} \mathrm{GAE} / \mathrm{g}, 61.64 \mathrm{mg} \mathrm{GAE} / \mathrm{g}, 69.87 \mathrm{mg}$ GAE/g and $50.69 \mathrm{mg}$ $\mathrm{GAE} / \mathrm{g}$ for the $30 \% \mathrm{CAC}+17.5 \% \mathrm{MS}: \mathrm{WPC}, \quad 17.5 \% \mathrm{CAC}+30 \% \mathrm{MS}: \mathrm{WPC}, \quad 30 \% \mathrm{CAC}+17.5 \% \mathrm{MS}: \mathrm{SPI}$ and 17.5\% CAC+30\%MS:SPI treatments, respectively (Table 2). As for the anthocyanin contents, the total phenolic contents were higher for powders with CAC of $30 \%$ and WPC proportion of $17.5 \%$.

The encapsulation efficiency varied from a minimum value of $99.26 \%$ to a maximum value of 99.74 (Table 2 ). Similar values were higher than for spray-dried jussara without carrier agents (Pereira et al., 2019). The encapsulation efficiencies are also related to the shelf life of the anthocyanin content and total phenolic contents of the powders. Consequently, the results obtained for these characteristics indicate that the combination of MS and WPC or SPI formed suitable chemical interactions that help retain the anthocyanins and phenolic compounds inside the wall material. The effectiveness of the interactions depends on the chemical and physical structure of each support material. 


\subsection{Scanning Electron Microscopy}

The morphology of the jussara pulp powder was evaluated by scanning electron microscopy (SEM) (Figure 2). Knowledge of the shape of particles is important because it can affect certain factors such as flowability of the powder, packing and interaction with fluids. Observing the external morphology, the particles showed a spherical shape and various sizes with no apparent cracks or fissures, which is an advantage, since it implies that the capsules have lower permeability to gases and increased protection and retention of the active material. However, variations in the roughness of the particle surfaces were observed and a variety in size, which is a typical characteristic of particles produced by spray drying.

Figure 2 - Micrographs of spray-dried jussara pulp powder. (a) and (b) correspond to the tests 30\%CAC+17.5\%MS:WPC and $17.5 \% \mathrm{CAC}+30 \% \mathrm{MS}: \mathrm{WPC}$, respectively, and (c) and (d) correspond to the tests $30 \% \mathrm{CAC}+17.5 \% \mathrm{MS}: \mathrm{SPI}$ and $17.5 \% \mathrm{CAC}+30 \% \mathrm{MS}: \mathrm{SPI}$, respectively.

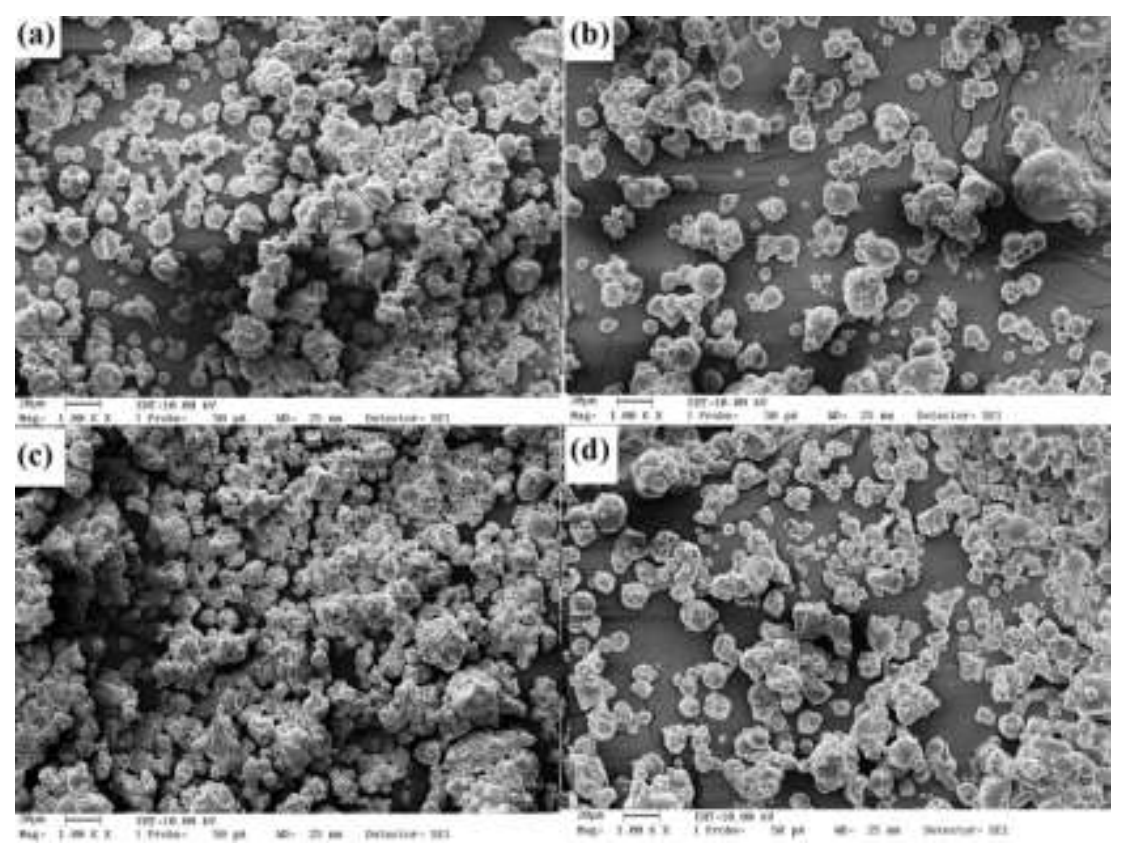

Source: Authors (2020).

The mixtures of different wall materials influenced the morphology of the microparticles. According to Brotel et al. (2014) the shapes are substantially dependent on the carrier used. This was more evident when comparing the images from the combination of MS:SPI (Figure. $2 \mathrm{c}$ and 2d) with those of MS:WPC (Figure 2a and 2b), since the latter resulted in microspheres with a smoother surface and fewer teeth or roughness.

According to Ré (1998), imperfections (teeth) are formed when there is a slow process of film formation during drying of the atomized droplets, associating the presence of surface depressions with the collapse suffered by the droplets during the initial stages of drying. In the present study, adding WPC may have improved the viscoelastic properties of the matrix, allowing for a smoother surface at the end of the drying process, or enabling the particles to dry more rapidly, thereby hindering shrinkage. It is also possible that these imperfections were caused by the collision of tiny particles (Zhang et al., 2018). Similar morphological characteristics were found by Tonon et al. (2011), Carneiro et al. (2013) and Rocha et al. (2018). In all these studies, the microcapsules presented similar external globular morphology, resulting from the fast water evaporation during the spray drying process. Furthermore, the lack of wall fissures or porosity on the particle surface indic ated complete coverage of the core by the carriers. 
According to Figure ( $2 \mathrm{a}$ and $2 \mathrm{~b})$ and $(2 \mathrm{c}$ and $2 \mathrm{~d})$, the particles showed similarities between them, although the formulations shown in Figure. $2 \mathrm{a}$ and $2 \mathrm{~b}$ and in Table 2 are the formulations with the best anthocyanin and total phenolic compound contents and the best encapsulation efficiency (close to 100\%), amongst other characteristics, which means that more active material was encapsulated and embedded in the wall material matrix.

\section{Conclusion}

1. The wall materials used in this study improved wettability, anthocyanin content, total phenolic compound content and the encapsulation efficiency.

2. In the presence of WPC, the particles become more spherical, with fewer dents. The value of utilizing protein as the second wall material was reaffirmed in this present work, which described how these elements complemented the properties of the wall materials used to fabricate jussara pulp microparticles.

3. The usage of WPC or SPI mutually with MS is a valid option in the spray drying of jussara pulp. Generally, the results achieved in this work showed that good quality powders with a high level of anthocyanin and total phenolic compound could be formed by spray drying.

4. Moreover, there is a great potential for organoleptic analysis of the final product for applications in the food industry as a future work.

\section{Acknowledgments}

The authors are grateful to the Brazilian Government Agency CAPES for financial support.

\section{References}

Ahmed, M., Akter, M. S., Lee, J.-C., \& Eun, J.-B. (2010). Encapsulation by spray drying of bioactive components, physicochemical and morphological properties from purple sweet potato. LWT - Food Science and Technology, 43(9), 1307-1312. https://doi.org/10.1016/j.lwt.2010.05.014

AOAC. (2016) Official method of analysis of the Association of Official Analytical Chemists (18th ed.). Gaithersburg, Maryland.

Barbosa, M. I. M. J., Borsarelli, C. D., \& Mercadante, A. Z. (2005). Light stability of spray-dried bixin encapsulated with different edible polysaccharide preparations. Food Research International, 38(8-9), 989-994. https://doi.org/10.1016/j.foodres.2005.02.018

Borges, G. D. S. C., Vieira, F. G. K., Copetti, C., Gonzaga, L. V., \& Fett, R. (2011). Optimization of the extraction of flav anols and anthocyanins from the fruit pulp of Euterpe edulis using the response surface methodology. Food Research International, 44(3), 708-715. https://doi.org/10.1016/j.foodres.2010.12.025

Botrel, D. A., de Barros Fernandes, R. V., Borges, S. V., \& Yoshida, M. I. (2014). Influence of wall matrix systems on the properties of spray-dried microparticles containing fish oil. Food Research International, 62, 344-352. https://doi.org/10.1016/j.foodres.2014.02.003

Carneiro, H. C. F., Tonon, R. V., Grosso, C. R. F., \& Hubinger, M. D. (2013). Encapsulation efficiency and oxidative stability of flaxseed oil microencapsulated by spray drying using different combinations of wall materials. Journal of Food Engineering, 115(4), 443-451. https://doi.org/10.1016/j.jfoodeng.2012.03.033

Cen, H., Bao, Y., He, Y., \& Sun, D.-W. (2007). Visible and near infrared spectroscopy for rapid detection of citric and tartaric acids in orange juice. Journal of Food Engineering, 82(2), 253-260. https://doi.org/10.1016/j.jfoodeng.2007.02.039

Cinquanta, L., Di Matteo, M., \& Esti, M. (2002). Physical pre-treatment of plums (Prunus domestica). Part 2. Effect on the quality characteristics of different prune cultivars. Food Chemistry, 79(2), 233-238. https://doi.org/10.1016/S0308-8146(02)00138-3

de Beer, D., Pauck, C. E., Aucamp, M., Liebenberg, W., Stieger, N., van der Rijst, M., \& Joubert, E. (2018). Phenolic and physicochemical stability of a functional beverage powder mixture during storage: effect of the microencapsulant inulin and food ingredients. Journal of the Science of Food and Agriculture. https://doi.org/10.1002/jsfa.8787

de Brito, E. S., de Araújo, M. C. P., Alves, R. E., Carkeet, C., Clevidence, B. A., \& Novotny, J. A. (2007). Anthocyanins Present in Selected Tropical Fruits: Acerola, Jambolão, Jussara, and Guajiru. Journal of Agricultural and Food Chemistry, 55(23), 9389-9394. https://doi.org/10.1021/jf0715020

Edris, A. E., Kalemba, D., Adamiec, J., \& Piątkowski, M. (2016). Microencapsulation of Nigella sativa oleoresin by spray drying for food and nutraceutical applications. Food Chemistry, 204, 326-333. https://doi.org/10.1016/j.foodchem.2016.02.143 
Fang, Z., \& Bhandari, B. (2011). Effect of spray drying and storage on the stability of bayberry polyphenols. Food Chemistry, $129(3)$, 1139-1147. https://doi.org/10.1016/j.foodchem.2011.05.093

Ferrari, C. C., Germer, S. P. M., Alvim, I. D., Vissotto, F. Z., \& de Aguirre, J. M. (2012). Influence of carrier agents on the physicochemical properties of blackberry powder produced by spray drying. International Journal of Food Science \& Technology, 47(6), 1237-1245. https://doi.org/10.1111/j.13652621.2012.02964.x

Francis, F. J. (1982). Anthocyanins as Food Colors. In: Markasis, P., Analysis of anthocyanins. Academic Press, Cap. 5, p.182-205.

García-Lucas, K. A., Méndez-Lagunas, L. L., Rodríguez-Ramírez, J., Campanella, O. H., Patel, B. K., \& Barriada-Bernal, L. G. (2017). Physical properties of spray dryed Stenocereus griseus pitaya juice powder. Journal of Food Process Engineering, 40(3), e12470. https://doi.org/10.1111/jfpe.12470

Hinneburg, I., Damien Dorman, H. J., \& Hiltunen, R. (2006). Antioxidant activities of extracts from selected culinary herbs and spices. Food Chemistry, 97(1), 122-129. https://doi.org/10.1016/j.foodchem.2005.03.028

I Ré, M. (1998). Microencapsulation By Spray Drying. Drying Technology, 16(6), 1195-1236. https://doi.org/10.1080/07373939808917460

Jafari, S. M., Ghalegi Ghalenoei, M., \& Dehnad, D. (2017). Influence of spray drying on water solubility index, apparent density, and anthocyanin content of pomegranate juice powder. Powder Technology, 311, 59-65. https://doi.org/10.1016/j.powtec.2017.01.070

Maia, P. D. D. S., dos Santos Baião, D., da Silva, V. P. F., de Araújo Calado, V. M., Queiroz, C., Pedrosa, C., Valente-Mesquita, V. L., \& Pierucci, A. P. T. R. (2019). Highly Stable Microparticles of Cashew Apple (Anacardium occidentale L.) Juice with Maltodextrin and Chemically Modified Starch. Food and Bioprocess Technology, 12(12), 2107-2119. https://doi.org/10.1007/s11947-019-02376-x

Nambi, V. E., Manickavasagan, A., Thangavel, K., Aniesrani, D. S., Chandrasekar, V., \& Raghavan, G. S. V. (2017). Effect of carrier material on flow characteristics of date pulp feedstock. Drying Technology, 35(1), 116-124. https://doi.org/10.1080/07373937.2016.1162170

Paim, D. R. S. F., Costa, S. D. O., Walter, E. H. M., \& Tonon, R. V. (2016). Microencapsulation of probiotic jussara (Euterpe edulis M.) juice by spray drying. LWT, 74, 21-25. https://doi.org/10.1016/j.1wt.2016.07.022

Pereira, D. C. de S., Beres, C., Gomes, F. dos S., Tonon, R. V., \& Cabral, L. M. C. (2020). Spray drying of juçara pulp aiming to obtain a "pure” powdered pulp without using carrier agents. Drying Technology, 38(9), 1175-1185. https://doi.org/10.1080/07373937.2019.1625363

Reineccius, G. A. (2004). The Spray Drying of Food Flavors. Drying Technology, 22(6), 1289-1324. https://doi.org/10.1081/DRT-120038731

Rocha, J. de C. G., de Barros, F. A. R., Perrone, I. T., Viana, K. W. C., Tavares, G. M., Stephani, R., \& Stringheta, P. C. (2019). Microencapsulation by atomization of the mixture of phenolic extracts. Powder Technology, 343, 317-325. https://doi.org/10.1016/j.powtec.2018.11.040

Santana, A. A., Cano-Higuita, D. M., de Oliveira, R. A., \& Telis, V. R. N. (2016). Influence of different combinations of wall materials on the microencapsulation of jussara pulp (Euterpe edulis) by spray drying. Food Chemistry, 212, 1-9. https://doi.org/10.1016/j.foodchem.2016.05.148

Shishir, M. R. I., \& Chen, W. (2017). Trends of spray drying: A critical review on drying of fruit and vegetable juices. Trends in Food Science \& Technology, 65, 49-67. https://doi.org/10.1016/j.tifs.2017.05.006

Tonon, R. V., Brabet, C., \& Hubinger, M. D. (2008). Influence of process conditions on the physicochemical properties of açai (Euterpe oleraceae Mart.) powder produced by spray drying. Journal of Food Engineering, 88(3), 411-418. https://doi.org/10.1016/j.jfoodeng.2008.02.029

Tonon, R. V., Brabet, C., Pallet, D., Brat, P., \& Hubinger, M. D. (2009). Physicochemical and morphological characterisation of açai ( Euterpe oleraceae Mart.) powder produced with different carrier agents. International Journal of Food Science \& Technology, 44(10), 1950-1958. https://doi.org/10.1111/j.1365-2621.2009.02012.x

Zhang, L., Zeng, X., Fu, N., Tang, X., Sun, Y., \& Lin, L. (2018). Maltodextrin: A consummate carrier for spray-drying of xylooligosaccharides. Food Research International, 106, 383-393. https://doi.org/10.1016/j.foodres.2018.01.004 